\title{
sciendo CREATING PARTICIPATION OF EMPLOYEES \\ IN IMPROVING WORK SAFETY IN ENTERPRISE
}

doi:10.2478/mape-2018-0087

Date of submission of the article to the Editor: 03/2018

Date of acceptance of the article by the Editor: 07/2018

MAPE 2018, volume 1, issue 1, pp. 689-694

\author{
PhD. Anna Gembalska-Kwiecień \\ PhD. Eng. Bożena Skotnicka-Zasadzień \\ Assoc. Prof., PhD., Eng. Radosław Wolniak \\ Silesian University of Technology, Poland
}

Ing. Marián Bujna, PhD.

Slovak University of Agriculture in Nitra, Slovak Republic

\begin{abstract}
The article deals with the issue of employees' participation in the security management system in an enterprise. The issue of participation was presented as well as empirical studies illustrating the problem of the study. The benefits from the creative participation of employees in a safety management system were also shown. It was stated that an employee's participation in specific areas of business management is important and that it is a desirable direction in the development of the employees' staff and displaying joint responsibility for the workplace. The research was carried out in five enterprises engaged in the business of construction and renovation activities. The surveyed employees were employed in various positions and at various organizational levels, they took part in the survey and in individual interviews. Questions from the first part of the questionnaire generally concerned issues related to occupational health and safety. The second part concerned issues directly related to the safety management system as well as the creativity and participation of employees in improving work safety in the surveyed enterprise. Empirical studies have shown that some of the surveyed employees have a rather passive attitude towards systemic issues. The article uses the approach that puts human events in the epicenter as one of the most important drivers of changes taking place in enterprises. In order to further improve the functioning of the implemented and maintained systems, enterprises have created their own set of practiced forms of employee participation.
\end{abstract}

Keywords: creativity, complicity in management, employee participation, enterprise management, work safety

\section{INTRODUCTION}

Managing enterprises nowadays is extremely difficult. This process is a combination of many elements that are interrelated. According to Griffin, management is „a set of activities (planning, organizing, motivating and controlling) directed at the resources of organizations used with the intention of achieving its goals" (Griffin, 1999). The combination of the above elements is revealed in every organizational unit, however, this process takes place in various ways depending on the specificity of the given enterprise. There is no "golden mean" to define the universal way of effective management.

Today's enterprises have to put a lot of effort to adapt the right form of this complex process to their enterprise and to provide an adequate material and human capital. Above all, they must realize that effective management of the entire organization is inseparably connected with employees. Therefore, they should adequately take care of the selection of the employees already during recruitment.

Each employee, regardless of his or her position in the organizational structure, is coresponsible for the success of the entire enterprise and is an important link in its development. 
In addition, as a human being, he or she can be a huge potential for knowledge that can be used to solve many management problems.

Co-decision of employees, manifesting in the form of participation, is very beneficial for the enterprise and effective in increasing the efficiency of its management. Creative employee participation, especially in matters related to security management, is an important element enabling improvement of working conditions and raising the level of security in the enterprise. A man is in itself a great risk to himself and others, hence it is important that he wants to take care of his safety and improve the conditions in which he is to work. To this end, many forms of participation have been created, which makes it possible to choose the right method for the character of the enterprise and the people employed in it. However, it takes time to create an effective participatory program, but this is not a waste of time. The benefits of this are mutual and bring positive results (Gembalska-Kwiecień, 2017a; 2017b).

\section{THE ISSUE OF PARTICIPATION}

The word participation derives from the Latin word „partycipo”, which means „to participate, share something and take part in something" (Russell, 2002). In Polish literature and journalism, this phrase is a synonym of co-management, however, it refers directly to a specific group or team. Participation cannot be identified with a particular unit because it only exists in multi-stakeholder activities. There were many definitions of this issue and in each case the authors drew attention to its other aspects. However, in most definitions, some common elements can be identified which fall within the conceptual scope of the issue. These include: influence, interaction and information exchange. Exerting influence is the most important element of participation because it is connected with exercising power. According to Max Weber, power is "the probability that some or all of the commands coming from a given source will be heard in a given group of people”. In other words, power is simply "the ability to influence the behavior of others" (Griffin, 1999). The second element of participation are interactions understood as "mutual, direct interaction of two or more persons". Thanks to them, individual interest groups can cooperate with each other and solve selected problems. The third and last element is the exchange of information. It is necessary to interact and to get an agreement between people participating in the participation. Summing up, participation will not be able to occur without any of the above elements, because they constitute a definite whole, depicting its core.

The basic function of participation is to seek the empowerment of employees. The concept of subjectivity is understood as a situation "in which a person or group of people, realizing a conscious influence on matters important to themselves, achieves results that are unequivocally satisfactory in self-assessment and significant in the overall balance of organizational influences". By fulfilling this function, employees are satisfied with the need for their self-fulfillment, recognition or dignity, as well as an appropriate place in the organizational structure of the enterprise and their interests are taken into account (Gembalska-Kwiecien, 2017c; Wolniak et al., 2017). Thanks to this, employees are aware that they have an influence on their own behavior and that they are responsible for their own actions. In addition to the function of empowering people in organizing work, other values of participation have also been determined, influencing the roles, diversity of roles, multilateral information relations between the participants of the organization, negotiations, changing the orientation of the management from the individual to the group, satisfying the needs of a higher order, both subordinates and superiors, organizational orientation on efficiency, displaying trust and tolerance (Parker, 1998; Zasadzień, 2017). 


\section{BENEFITS RESULTING FROM THE CREATIVE PARTICIPATION OF EMPLOYEES IN THE SAFETY MANAGEMENT SYSTEM}

The top management of each organizational unit must realize that "management is simply too important to leave them to the managers" and encourage employees to cooperate (Kleniewski, 2004; Kontogiannis et al., 2017). The term "management” in this context applies to both the entire organization and to matters related to security. All possibilities of employee involvement in the enterprise's affairs, especially those related to security management, have impact on the integration of employees with the enterprise and bring many benefits.

The involvement of employees in making decisions related to safety, increases the satisfaction with the work performed and causes the person to identify with the enterprise. Employees' involvement in problems related not only to their daily duties causes themselves to begin to broaden their horizons of interest and reflect on improving the prevailing conditions. Being aware of the fact that they influence the fate of the enterprise gives them enormous satisfaction and willingness to act. However, in order for the employee to become involved in the organization's affairs, he must obtain some benefits, which often include financial benefits, all kinds of praise on the part of management, a sense of appreciation, or the possibility of his own development. It is also necessary to satisfy the need for the subjectivity of employees by granting them the right place in the organization and taking into account their interests in all activities of the enterprise (Brodny et al., 2016; Brodny et al., 2017). In a situation when a person realizes that he can influence the reality that surrounds him, he begins to think about what he is doing and anticipate the consequences of his actions. The ability to decide for yourself makes people shape non-standard and creative behaviors, which becomes a collection of atypical, but sometimes very accurate solutions.

The enterprise, thanks to the involvement of employees, gains a lot. Mainly because the increased employee satisfaction from the work caused by participation will increase their efficiency and productivity, and thus automatically increase the enterprise's performance. The evidence for this is the research carried out by the European Foundation for the Improvement of Living and Working Conditions within the framework of the EPOC Project - „Employee direct participation in organizational change". The project concerned 10 European Union countries and was implemented in 1993-1998. The obtained results confirmed the economic benefits for companies resulting from employee participation. It was found that thanks to the involvement of employees there was a reduction in costs (in about $40 \%$ of private companies), improvement in quality (in about $90 \%$ of companies), increase in production (in about $40 \%$ of companies), fall in cases (in about $30 \%$ of companies) or decrease absences - in about $35 \%$ of companies (Sisson, 2000). An enterprise can achieve benefits only and exclusively thanks to well-chosen staff, characterized by creative thinking and creativity, which form the basis of innovation in operation. Involvement of employees in activities related to occupational health and safety and the ability to make decisions independently means that employees identify themselves with the enterprise and the decisions they make. Therefore, a participatory system should be developed in the enterprise, putting a slightly greater emphasis on the direct participation of employees in matters related to the system, as this can help in solving problems and improve the implemented system.

\section{RESULTS OF THE RESEARCH}

The research was carried out in five companies dealing with construction and renovation activities. The surveyed employees were employed in various positions and at various organizational levels, they took part in the survey and in individual interviews. The questions from the first part of the questionnaire generally concerned issues related to occupational health and safety. The second part concerned issues directly related to the safety management system as well as the creativity and participation of employees in improving work safety in the surveyed enterprise $324(60.2 \%)$ people on 538 employees in the surveyed enterprises took part in the survey. There were 302 manual workers $(93.2 \%)$ and 22 white- 
collar workers (6.8\%) among the respondents. The examined enterprise also conducted an analysis of system documentation related to the safety management system according to PN$\mathrm{N} 18001$ in order to show the possibilities and forms of employee participation in related matters. To this end, the procedures, instructions and regulations in force in the enterprise were analyzed. The next stage of the research was conducting a survey. The survey questionnaire was developed based on the requirements of PN-N 18001.

As a result of the analysis of documentation in the enterprise, it was found that the highest management of the enterprise decided to implement and certify management systems:

- quality according to PN-EN ISO 9001 - the year of implementation 2004,

- environmental according to the PN-EN ISO 14001 standard - implementation year 2005,

- safety according to PN-N 18001 - implementation year 2005.

The implemented quality management system according to the PN-EN ISO 9001 standard is helpful in management throughout the enterprise's operations. It provides a kind of guarantee that the enterprise maintains the desired quality of services provided. This system, properly implemented and maintained, forms the basis of modern enterprise development, while at the same time offering extensive reorganization opportunities. The Environmental Management System according to PN-EN ISO 14001 is part of the entire enterprise management system. It includes the organizational structure, planning, responsibilities, executive practice, procedures, processes and resources to implement and manage in a manner that takes into account environmental problems. In order to improve working conditions, the enterprise implemented a safety management system according to PN-N 18001. The basic factor determining the structure of this system is the applicable law. The Polish PN-N 18001 standard is the supporting tool. The main objective of PN-N 18001 is to create rules of conduct for all employees of the enterprise in the area of activities aimed at shaping and improving work safety (Polski Komitet Normalizacyjny, 2001, 2004a, 2004b). As a result of the survey, it was stated that the management puts a lot of emphasis on safety and improvement of working conditions with the participation of employees of the enterprise, which was noticed and appreciated by its employees. Based on the survey, $69.9 \%$ believe that the enterprise cares for safe working conditions, while the remaining $30.1 \%$ have reservations about it. Among white-collar workers, $76 \%$ are satisfied with safe working conditions, and $24 \%$ have certain reservations. In the case of manual workers, $62.1 \%$ are also satisfied, and $37.9 \%$ would like to make some changes. Most of the surveyed employees, as many as $91.4 \%$ think that they are co-responsible for safe working conditions. Participation in security management in the enterprise is very important for them. The fact that management counts with their opinions, introduces many crew ideas, gives employees a sense of greater responsibility for security and greater development opportunities. Therefore, $82.5 \%$ of manual workers say they should be involved in decision making on security management, and $72 \%$ of white-collar workers also have the same opinion on this subject.

An important requirement of the PN-N 18001 standard is the obligation of the employer to organize consultations with employees aimed at improving the working conditions and functioning of the system.

\section{CONCLUSION}

The conducted research allowed to show the enterprise's participatory system, where indirect participation is predominantly dominating, manifested by the fact that employees express their opinions on topics related to work safety through their designated representatives. Empirical research has shown that some of the surveyed employees have a rather passive attitude towards systemic issues, and sporadically, mostly in a small group of colleagues, they talk about topics related to occupational health and safety. It was found that: 
- in security management, the greatest attention should be given to man as the subject of all activities, because the human factor is the cause of most accidents, and the other factors often referred to as the labor factor lose their importance when new technologies and materials are used to ensure greater safety;

- only by working out and then shaping healthy habits of employees, it is possible to support the creation of a healthy society;

- all employees, at all levels - without exception - must be involved in a modern enterprise in creating the desired safety culture. Every private employee must really see respect and comply with health and safety regulations;

- it seems necessary to stimulate healthy motivation for safe work among the crew, through its activation and implementation of jointly developed solutions aimed at preventing and promoting health in combating occupational diseases, proper selection for work and the correct process of employee's professional adaptation. Dedication to the employee at that time, and the elimination of employees who do not comply with the regulations and rules of health and safety, and the tendency to risky behaviors;

- introducing education and activities aimed at reducing the distress of employees resulting from the specificity of work, as well as working out methods of dealing with it.

\section{ACKNOWLEDGEMENTS}

This article is the result of research conducted at the Institute of Production Engineering, Faculty of Organization and Management, Silesian University of Technology, within the statutory work entitled „Development of intelligent production methods as well as work and life environments in the context of production engineering challenges" (symbol 13/030/BK_18/0039).

\section{REFERENCES}

Griffin, R. (1999). Podstawy zarządzania organizacjami. Warszawa: Wydawnictwo Naukowe PWN.

Brodny, J., Alszer, S., Krystek, J. and Tutak, M. (2017). Availability analysis of selected mining machinery. Archives of Control Sciences, 27(2), pp. 197-209.

Brodny, J., Stecuła, K. and Tutak, M. (2016). Application of the TPM strategy to analyze the effectiveness of using a set of mining machines. In. 16th International Multidisciplinary Scientific GeoConference SGEM 2016. Science and Technologies in Geology, 2, pp. 65-72.

Gembalska-Kwiecień, A. (2017a). Development of an innovative methodology supporting project risk management in the manufacturing company of the automotive industry. In. 6th International Conference on Operations Research and Enterprise Systems ICORES 2017. Setúbal: SciTePress - Science and Technology Publications, pp. 265-271.

Gembalska-Kwiecień, A. (2017b). Improvement of the work safety management system in hard coal mining with special reference to the problem of workers participation. In. 17th International Multidisciplinary Scientific GeoConference SGEM 2017. Science and Technologies in Geology, Exploration and Mining, 17(13), pp. 429-436.

Gembalska-Kwiecień, A. (2017c). Improving safety culture in the enterprise based on attitudes and behavior of its employees. In. 9th International Conference on Applied Economics Contemporary Issues in Economy.

Kleniewski, K. (2004). Integracja systemów zarządzania jakością, środowiskiem, bezpieczeństwem i higieną pracy. Problemy Jakości, 36(11), pp. 8-10.

Kontogiannis, T., Leva, M.C. and Balfe, N. (2017). Total Safety Management: Principles, processes and methods. Safety Science, 100, pp. 128-142.

Parker, T. (1998). Total Cost Indicators. Operational Performance Indicators for managing environmental and economic efficiency. Bachelor thesis. International Institute for Industrial Environmental Economics, Lund University, Lund.

Polski Komitet Normalizacyjny, (2001). Norma PN-EN ISO 9001:2001 Systemy zarządzania jakością Wymagania. Warszawa: PKN.

Polski Komitet Normalizacyjny, (2004a). Norma PN-N-18001:2004 Systemy zarzadzania bezpieczeństwem i higieną pracy - Wymagania. Warszawa: PKN.

Polski Komitet Normalizacyjny, (2004b). Norma PN-EN ISO 14001:2004 Systemy zarządzania środowiskowego - Specyfikacja i wytyczne stosowania. Warszawa: PKN.

Russell, S. (2002). ISO 9000:2000 and the TQM excellence model: competition or co-operation. Total Quality Management, 11(4-6), pp. 657-665. 
Sisson, K. (2000). New Forms of Work. Can Europe Realize Its Potential? Results of a survey of direct participation in Europe. [online] Dublin: European Foundation for the Improvement of Living and Working Conditions. Available at:

http://www.eurofound.europa.eu/ef/sites/default/files/ef_files/pubdocs/1998/03/en/1/ef9803en.pdf [Accessed 23 Mar. 2018].

Wolniak, R.,. Skotnicka-Zasadzień, B. and Zasadzień, M. (2017). Application of the theory of constraints for continuous improvement of a production process - case study. In. 3rd International Conference on Social, Education and Management Engineering - SEME. [online] Lancaster: DEStech Publications, pp. 169-173. Available at: http://dpiproceedings.com/index.php/dtssehs/article/download/18023/17529 [Accessed 23 Mar. 2018].

Zasadzień, M. (2017). Application of the Six Sigma method for improving maintenance processes - case study. In. 6th International Conference on Operations Research and Enterprise Systems ICORES 2017. Setúbal: SciTePress - Science and Technology Publications, pp. 314-320. 